\title{
On Cavity Parenchyma and Tyloses in Ferns.
}

\author{
BY \\ MARY MCNICOL, B.Sc., \\ Beyer Fellow in the Universily of Masuchester.
}

With Plate $X X V$ and seven Figures in the Tert.

7 HE term 'cavity parenchyma' has been used to indicate a special kind protoxylem groups. It consists of soft cells of a more or less irregular shape, forming vertical strands of loose large-celled parenchyma which replaces to a greater or less degree the first-formed elements of the xylem. Such parenchyma is formed from the one-layered sheath of soft cells immediately surrounding the protoxylem. The sheath cells in contact with the spiral vessels become enlarged and send ingrowths between the spiral thickenings into the lumina of the vessels. The result of further protrusion of the parenchyma cells into the vessels is that more or less spherical, swollen processes are formed, and the vessels become gradually broken up by the increasing pressure of these processes within the passages, the place of the spiral vessels being eventually taken by the parenchyma so formed. Russow proposed the name 'Liickenparenchym' for the soft cells filling up the cavity left by the tearing of the tissues near the protoxylem in Marsilia.

One of the earliest writers to mention strands of soft cells was Dippel ('64), who noticed them in Osmunda and in Cyathea microlepis; Terletzski ('84) also found them in Pteris aquilina and Struthiopteris germanica: he considered them to be part of the wood tissue, for, he says, they border directly on the protoxylem, and never directly on the bast cells and sievetubes, from which they are always separated by the parenchymatous sheath. Boodle('01) gives a short account of cavity parenchyma in the Schizaeaceae ; he states that in Ameimia there are three groups belonging to the conjunctive parenchyma adjoining the xylem, one at the median point, the others at a short distance from each hook ; in Mohria there are also three groups of parenchyma (p. 359). In the Gleicheniaceae he mentions it as occurring in nearly all species, the cells frequently becoming thick-walled and lignified. Seward and Ford ('03), writing of Todea, state that 'the parenchymatous tissue abutting on the protoxylem strands occasionally forms small irregular cavities (cavity parenchyma),' p. 247; Seward ('99) mentions it also in

[Annals of Botang, Vol. XXII. Ho. LIXXVII. July, 1908.] 
Matonia, p. I 83, but no details are given. Farmer in the same year ('99), referring to Helminthostackys, writes that the protoxylem groups 'are often seen to border on a band of peculiar parenchyma similar to that which Russow termed Lückenparenchym. The cells of this tissue are large and thin-walled ... the general impression which the observer acquires is that he is dealing with some kind of gland'.- p. 439. A somewhat unusual case of cavity parenchyma occurs in Loxsoma, where the cells become pitted and lignified, as recorded by Gwynne-Vaughan ('03), who states its formation to be due to a kind of tylosis. His figure showing some of the cavity parenchyma cells is reproduced in Pl. XXV, Fig. I7. Thus in all the large orders of modern Filicales and in Marsilia cavity parenchyma has been mentioned as present by different authors, and in one or two cases has been described, notably in Loxsoma by Gwynne-Vaughan, and in Gleichenia and Tricko-. manes Prieurii by Boodle. In the following account of cavity parenchyma I shall refer first to a number of ferns, giving details in each case, and shall then consider the function of the tissue.

A typical case of cavity parenchyma occurs in Microlepia platyphylla,

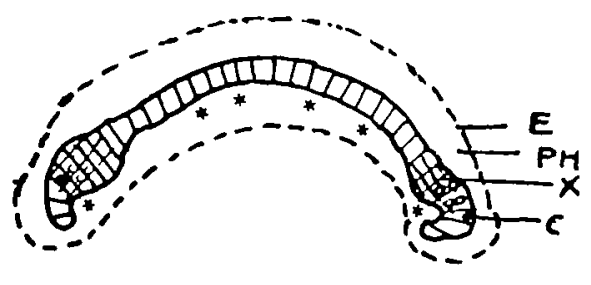

TEXT-FIG. I. Diagram of the petiolar bundle of Microlepia platyphylla.

$E$, endodermis. $X$, xylem.

PH, phloem. C, wood-parenchyma. one of the Polypodiaceae. In the petiole of this fern there is a single curved bundle, the ends being slightly hooked inwards; there is a group of protoxylem near each hook, and three or four groups lying between them (Text-fig. I). The position of the parenchyma strands is shown by crosses.

An enlarged view of one of the median strands in transverse section is shown in Fig. I of the plate. The cavity parenchyma is well developed, though it does not attain the great development of the corresponding tissue in the Tree Ferns, which are exceptional in this respect. The following description of the method of formation of cavity parenchyma can be applied with slight modifications to all Ferns. The tissue is most apparent in the thicker parts of the petiole near the base; it is continued up the rachis to the younger parts, gradually becoming less apparent towards the apex. Towards the end of the rachis the first stages of the development of the cavity parenchyma can be best seen. The xylemsheath cells in contact with the protoxylem are seen to be somewhat enlarged : this enlargement results in their being pressed into close contact with the spiral vessels of the protoxylem; with further enlargement the parenchyma cells begin to press in between the spirally thickened portions of the vessels. The result is that a single parenchyma cell of the xylemsheath generally shows several outgrowths, the constrictions representing 


\section{McNicol.-On Cavity Parenchyma and Tyloses in Ferns. 403}

the points of resistance of the lignified parts of the vessel. The continued expansion of the parenchymatous processes within the lumina of the vessels results in the breaking up of the vessels, which thus early become nonfunctional. Frequently nuclei are distinctly seen in the bladder-like swellings in the vessels; the swellings are finally cut off from the original cell by a cross-partition. After breaking up one spiral vessel the parenchyma continues its growth, forming new processes which penetrate adjoining vessels, and these in turn become broken up. In Microlepia most of the spiral vessels become broken up, but in some Ferns the parenchyma destroys only a few of the first-formed vessels. Their place is thus taken by irregular parenchyma cells, frequently with large intercellular spaces betiveen them, which form strands running the length of the petiole. Very frequently remains of the disintegrated vessels are seen in the spaces between the cells of the cavity parenchyma as small pieces of lignified thickening, sometimes two or three connected turns of a spiral, but generally small fragments considerably crushed. Such remains are to be noticed in the part of the parenchyma most recently formed; they are nearly always to be seen in the deep constrictions of the cells which have not ceased to expand, and they frequently give the cell itself a superficial appearance of being lignified at these points; in reality the tissue in this plant remains unlignified, though in various other Ferns lignification of the cavity-parenchyma cells does occur. In Fig. I three cavity-parenchyma cells are seen in cross-section at $c p$; they have replaced the protoxylem and have the appearance of extending a considerable distance into the phloem $p k$. The tissue is about one-fifth the width of the whole bundle. The metaxylem, which consists of a single row of tracheids, is seen at $x y$.

Cavity parenchyma has been recorded by Gwynne-Vaughan ('03) in Davallia, another member of the same sub-order. I examined D. Griffithiana, which has an elongated bundle, the xylem being surrounded by phloem about three cells deep; a group of cavity-parenchyma cells was seen at each end of the bundle, but the tissue, the cells of which are lignified in this species, did not occupy so large a space as in Microlepia. In Nephrolepis the vascular bundle is somewhat T-shaped or triangular, and the cavity parenchyma appears in the positions marked by stars in the Text-fig. I A, p. 404, opposite the three protoxylem groups. In longitudinal sections Nephrolepis shows very clearly the tylose-like swellings which occur in the spiral vessels. The Text-figs. 2, 3, 4, 5, show different stages of the ingrowth of the parenchyma.

Text-fig. 2 shows three cells of the xylem sheath which have formed small swellings in a vessel. Each cell had several swellings. Fig. 3 shows a stage in which the swellings have elongated, and have almost closed up the lumen of the vessel; Fig. 4 shows one swelling which has itself formed a swelling without being cut off from the original xylem-sheath cell by 
a cell-wall; Fig. 5 shows a series of three swellings in three distinct vessels, all formed from a single cell and not separated by cell-walls. This is quite common in Nephrolepis which shows perhaps better than any fern the tylose-like nature of the cavity parenchyma. The cells may eventually become cut off by cell-walls.

In Struthiopteris pennsylvanica, one of the Aspidieae, the petiolar bundle is much elongated and the cavity parenchyma is only slightly developed; it can be seen adjoining the two groups of protoxylem near the ends of the bundle; at these points the sheath cells were slightly enlarged, and remains of the disintegrated vessels were to be seen between them. In longitudinal section some of the cells are seen to be crenulated

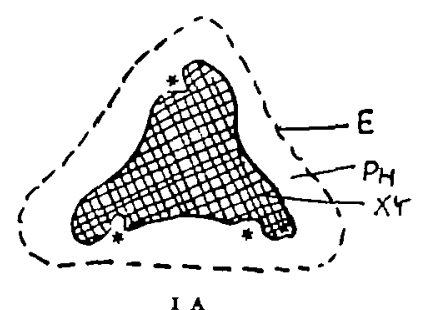

Text-Fig. I A. Diagram of petiolar bandle of Nephrolspis.

E, endodermis. XY, metaxylem.

$\mathrm{PH}$, phloem.
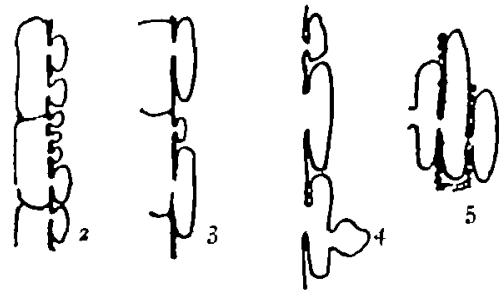

TEXT-FIGS. 2, 3, 4, 5.

Stages of formation of cavity parenchyma in Nephrolepis.

in outline on the side adjoining the spiral vessels, but the development of the tissue is not striking.

In Aspidium Filix-mas, in which the bundles are numerous and more or less rounded in form when seen in transverse section, and the vascular elements are narrow, there was no trace of cavity parenchyma, but longitudinal sections showed a slight bulging of a few sheath cells, though no actual ingrowth to the vessels was to be seen. In the petiole of Sadleria cyatheoides a Fern of tree-like habit, which I examined as dried material only, the cavity parenchyma was slightly developed. In Lomaria gibba, a form having small round bundles, the parenchyma was distinct in some bundles and not to be seen in others in the same cross-section. The cells were about the width of one of the wide tracheids of the bundles. There was no cavity parenchyma in Asplenium Ruta-muraria, but one or two cells were to be seen which had apparently enlarged, and slightly crushed an adjoining spiral vessel. In the sub-order Pterideae I examined Pteris aquilina, Gymnogramme ochracea, and Cheilanthes pulverescens, in the first of which cavity parenchyma was recorded by Terletzski ('84), as mentioned above. It is also present in the two lastmentioned Ferns. In Pteris the tissue is more striking than in G'mnogramme; 
it attains a width about one-fourth or one-fifth that of the bundle. Fig. 2 is a longitudinal section of Pteris aquilina showing the general appearance of a strand of cavity parenchyma $c p$; it will be noticed that the strand is one or two cells wide, and that the cells themselves are very irregular in shape. Fig. 3 shows the expansion $t y$ of the parenchyma cells in a spiral vessel. Disintegrated portions of the vessel are seen at $p x^{1}$ and a nucleus at $n$; a pitted tracheid occurs at $m x$. Fig. 4 shows a more advanced stage in the cavity-parenchyma formation. Fig. 5 shows a transverse section of a single strand of cavity parenchyma. Johnson ('03) gives an account of some tyloses which he found in a preparation of the rhizome of the Bracken Fern; the appearance of the preparation, of which a photograph is given, exactly. resembles the longitudinal sections of Pteris petiole showing cavity parenchyma. The soft cells figured appear to be in contact with the narrow elements of the xylem, the wider tracheid being at a greater distance. The preparation was made from a small detached piece of material by one of the students of his class, and it seems possible that either it may have been made from a piece of petiole, the tylose-like cells being cavity parenchyma, or that if cut from the rhizome it represents an unusual case of continuation of the cavity parenchyma in the rhizome. True tyloses formed in the wide pitted tracheids of stem-bundles are not known in recent ferns. In Gymnogramme and Cheilanthes there is a single petiolar bundle slightly hooked at each end, and in both these genera there is a strand of cavity parenchyma on the concave side of each of the hooks. Gymnogramme showed swellings of the xylem-sheath cells, one swelling sometimes giving rise to another without the formation of a dividing wall.

Although in a number of Polypodiaceous Ferns cavity parenchyma is well developed, it is in the histologically related group of the Cyatheaceae or Tree Ferns that the tissue attains its greatest development.

In Alsophila excelsa the vascular bundles of the petiole are elongated and crenulated, the protoxylem groups being situated in the little bays so formed. A single petiole has about forty or more groups and consequently has an equal number of cavity-parenchyma strands. A single strand attains a width of about one-third that of the bundle and the strands thus form a most conspicuous feature whether in transverse or longitudinal sections.

Text-fig. 6, p. 406, shows a transverse section of a petiole of Alsophila excelsa: in this section there were to be seen forty-four groups of protoxylem, each having a corresponding strand of cavity parenchyma. Longitudinal sections (see Fig. 6 in the plate) show that the cells are all quite parenchymatous, having thin cellulose walls, distinct nuclei and protoplasmic cell contents and that they are irregular in shape and have fairly large intercellular spaces. They replace many of the spiral elements of the xylem, and in transverse sections are seen to extend across the phloem, almost to the endodermis at times, as shown in Text-fig. 7, p. 406. 
In Dicksonia antarctica the extent of a single strand is much the same as in Alsophila, though sometimes a little narrower; but the cells themselves are considerably smaller, as shown in Fig. 7 in the plate; and whereas in Alsophila a transverse section frequently shows only one very large cell representing the whole strand, in Dicksonia a similar section will show several smaller cells. Figs. 6 and 7 are drawn with a camera lucida to the same scale. In Dicksonia the cells are lignified and rather small, in Alsophila they are unlignified and large. In Hemitelia, which I examined only as dried material, the cells were arranged as in Alsophila, the strands in the two being almost exactly the same width and generally one cell wide. In Cibotium princeps (Cyathea princeps, Hook.) a strand is generally

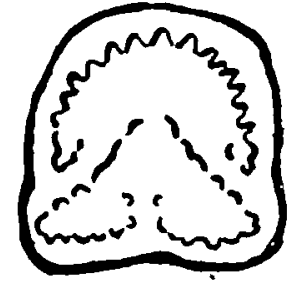

Text-pig. 6. Transverse section of petiole of $A$ lsophila excelsa showing the form of the vascular ban

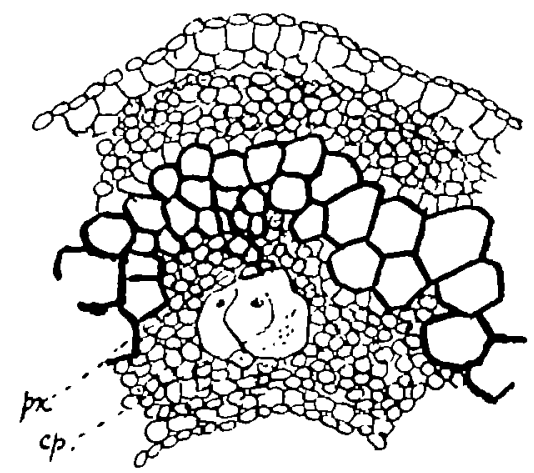

TeXT-Fig. 7. Transverse section of a single 'bay' in the vascular bundle of $A$. cxcelsa, showing cavity parenchyma $c p$ : the protoxylem $p x$ is not entirely destroyed.

two or three cells wide and is about half the width of the bundle: the phloem immediately opposite the protoxylem is almost entirely displaced by the growth of the cavity parenchyma. Fig. 8 shows a transverse section of a portion of a bundle of $C$. princeps. In this species the tissue showed an even greater development than in the other Tree Ferns mentioned, and showed, moreover, an interesting point which I have noticed in no other Fern. Most of the cells of the cavity parenchyma are thinwalled and of the usual nature: others, on the contrary, are reticulately thickened and lignified, and have all the appearance of water-storing tracheids. They resemble the 'Speichertracheiden' described by Haberlandt ('96). In almost any transverse section, providing it was not too thin, these lignified cells could be seen. Some of them are very large, being about a quarter or a third the width of the bundle itself, thus forming a very prominent feature. Fig. 8 shows three of these tracheids and Fig. 9 shows an enlarged view of part of the same preparation; at $p x$ is seen the protoxylem, and at $p x^{1}$ the spirally-thickened portions of some of the 
disintegrated protoxylem vessels. In longitudinal sections these cells are seen to be of various shapes, generally having a more or less spherical form, and frequently having an elongated vertical portion attached. In Fig. 9 two of these portions are shown cut across at $e t$. The tissue is formed in the usual way by the intrusion of the cells of the xylem sheath into the spiral vessels, which are thus disintegrated. In only one instance did I find parenchyma cells intruding into a wide pitted tracheid, and in this case the intrusive swellings were only small, and the markings on the tracheid-wall were for some reason unlignified. The other tracheids adjoining the unlignified one were normal in character; possibly the tracheid had become injured in some way, and so was weakened. The lignified cells of the cavity parenchyma are usually not actually in touch with the xylem of the vascular bundle, but may be isolated among a number of parenchyma cells. Fig. Io shows a group of these thickened cells of the cavity parenchyma in longitudinal view : as a rule they do not occur quite so many together. The cavity parenchyma cells are not lignified until the tissue has developed to a considerable extent and the spiral vessels are broken up: they do not become lignified when they are protruding as bladder-like processes into the lumina of the vessels: such lignification would, of course, prevent the further expansion and growth of the cell. Miss Jordan ('03) found that in an herbaceous stem of Cuctimis satizus there occurred tyloses having lignified walls, this lignification preventing the tyloses from extending far into the vessels, so that they never completely closed up the passages. The tyloses she figures resemble in appearance the lignified cells of the cavity parenchyma of Cibotium, which are formed in the first place by a process of tylosis, the difference being that whereas in Cucumis they are found actually within the lumen of the vessel, in Cibotium they have taken the place occupied by the spiral vessels of the protoxylem. The cells in Cibotizm recall to a slight extent the water-storing cells or transfusion tissue found in certain fossil plants, for cxample, in Megaloxylon, and the centripetal wood occurring in the peduncles and petioles of recent Cycads.

In the Hymenophyllaceae cavity parenchyma has been mentioned by Boodle in Trichomanes Prieurii, while absent in other species. In Hymenophyllum I found that though there was no trace of tylose-like formations, the spiral elements were broken up and the parenchyma cells enlarged; the narrow woody elements seemed to be broken up by the pressure of the swollen parenchyma cells outside, not by the pressure of intrusions into the lumina of the vessels; such a distinction in the formation of cavity parenchyma is, of course, one of degree only. In the Gleicheniaceae and in the Osmundaceae in Osmunda and Todea, cavity parenchyma has been recorded, as mentioned above. In the last named, the intercellular spaces in the tissue are large; the protoxylem seems to 
disintegrate, and its place may not be taken to any great extent by the xylem-sheath cells, so that frequently an actual cavity is seen.

In the Schizaeaceae Boodle recorded the tissue in Ancimia Phyllitidis. I examined $A$. fraxinifolia, which is regarded by Hooker as a subspecies of A. Phyllitidis; in this form there were four groups of cavity parenchyma in the petiolar bundle; the cells were lignified, and the nuclei very distinct. I found the tissue also in $A$. tomentosa but none in Lygoditm.

In Ophioglossum I found no cavity parenchyma, though the protoxylem cells become somewhat crushed by the soft cells adjoining them, and in Botrychium Lunaria and B. virginianum the same is the case. In Helminthostachys cavity parenchyma was recorded by Farmer as noted above. Such parenchyma occurs both in the fertile and sterile leaf-stalks, but is more evident in the sterile stalks. There are generally four or five enlarged cells to be seen in connexion with the protoxylem elements in any transverse section. Longitudinal sections show that the cells apparently crush the spiral vessels by lateral pressure; I found no definite tylose-like growths, such as occur, for example, in Pteris, though the edges of some of the cells were slightly crenulated. Fig. I I shows a semi-diagrammatic view of a cross section of Helminthostachys and Fig. I 2 is a longitudinal section of a single vascular strand.

In the group of Marattiaceous Ferns Brebner ('02) has recorded and described cavity parenchyma in Danaea. He says: 'the cavity due to the breaking down of the protoxylem is filled with parenchyma owing to the increase in size, accompanied by a greater or less amount of division, of the adjacent living cells... It is probably not of any physiological importance, being simply a case of non-pathological hernia, so to speak' (p. 544). In Marattia laxa and Angiopteris evecta cavity parenchyma is well developed. In the former the tissue can be seen opposite most of the bundles, though not always opposite the very small ones. There may be one or more groups to each bundle, according to whether it is short or elongated. Generally the cells lie in a little 'bay' and occupy only the place formerly occupied by protoxylem, not extending into the phloem; they do not, in spite of the large dimensions of the plants, attain the great size of the same cells in the Tree Ferns; as a rule they are only a little wider than the phloem cells. In Angiopteris the tissue is more strongly developed than in Marattia and the cells may be three or four times the width of the ordinary xylem-sheath cells. The strand is about one cell wide. Fig. I 3 shows a transverse section of a single bundle of Angiopteris evecta having one protoxylem group and a corresponding cavity-parenchyma strand $c p$ : the nuclei are distinct.

In Marsilia quadrifolia among the Water Ferns the tissue is very well developed; it occurs most distinctly near the protoxylem strand at the apex of the triangular bundle, as shown in Figs. 14 and 15 . At the other two 
points it is not noticcable in transverse view, though in longitudinal view the cells are seen to be enlarged and crenulated. Fig. I 6 is a section of the cavity parenchyma showing the lobed nature of the cells. In the Water Ferns, as in the Land Ferns, the cells grow out first into the lumina of the vessels by small swellings which enlarge within the passages.

With regard to the function of the cavity parenchyma thus widely distributed in Ferns, Dippel, writing of Osmunda, states that the strands are ' wahrscheinlich zur Aufnahme von Absonderungsprodukten bestimmt und den Harz-, Gummi und Milchsaftgängen der Phanerogamen an die Seite zu stellen'. Terletzski's view differed from this: his opinion was that the strands had 'keine andere Funktion als die Geleitzellen, da sie von diesen nur in Grösse und Form abweichen, aber im Bau der Wände und in Inhalt mit letzteren ubereinstimmen' (Terletzski '84, p. 464). It is very natural at first sight to look upon the strands, as did Dippel, as special secretory passages, for their appearance is so very unlike the normal arrangement of the wood-parenchyma cells, but the view is incorrect. The cells are generally, it is true, of an ordinary parenchymatous nature, as Terletzski thought, but in a considerable number of Ferns, for example, in Dicksonia antarctica and in Loxsona their walls are lignified. Such lignification might indicate that the function of the tissue was mechanical; the spiral vessels early become functionless, being broken up by the cells of the xylem sheath, and their place taken by a new tissue. Such a tissue would naturally be much stronger if the cells were lignified, and to a certain extent the tissue may have this function. In Cibotium princeps some of the cells are reticulately lignified, whilst others are entirely unlignified. Possibly this lignification is to compensate for the disintegration of the spiral vessels, the amount of conducting tissue being thereby very slightly lessened, but as the lignified cells are not all actually in contact with each other, and are often isolated, either singly or in groups, such a theory is hardly applicable. In the Equiseta, Strasburger states that the watery sap travels along the carinal canals and passes from one canal to another at the nodes by means of large pitted tracheids which form a connected mass. Large swollen parenchymatous cells near the tracheids frequently project into the carinal canals and have something the appearance of cavity parenchyma cells, though otherwise in the Equiseta the protoxylem is replaced by a canal which is used for water-conduction. But as in the Ferns, the ordinary tracheids composing the metaxylen are sufficient to carry the stream of water up the plant, it seems likely that the tracheids found in the cavity parenchyma of Cibotium are simply for storing water, and that in other Ferns where lignification of all the cells occurs, the tissue performs the same function. The need for such a storage of water in some Ferns is indicated in Todea superba in which Seward and Ford ('03) describe some tracheids of great breadth found here and there in the xylem 
of the stem : 'the large diameter and short length suggest a storage rather than a conducting function,' p. 248 .

At the same time the cells probably act to a certain extent as strengthening tissue. Thus in Phanerogams and Ferns there are instances of the lignification of tyloses resulting in cells which have all the appearance of water-storing cells.

Cavity parenchyma is to be regarded as a special tissue formed by the conjunctive parenchyma cells of the vascular bundles of the petiole, which replaces the first-formed elements of the wood, sometimes by simply crushing the spiral vessels, but generally by means of tylose-like swellings within the cavity of the vessels. True tyloses, that is, soft cells which enter the wide tracheids or vessels and remain within them, simply closing up the cavities by the formation of a pseudo-parenchyma, are unknown in recent vascular cryptogams, except in a case mentioned by Conwentz, who found tyloses in the old leaf-stalks of Cyathea insignis, and in the case mentioned by Johnson in the rhizome of Pteris aquilina; they occur frequently in monocotyledons and dicotyledons where, on account of the large amount of conducting tissue, the advantage of stopping up some of the wood vessels can be readily understood. In the fossil Fern petiole. Racliopteris insignis, now known to have belonged to Zygopteris corrugata, the xylem elements are often seen to be entirely closed up by soft parenchyma cells. It is a matter of some difficulty to explain the presence or function of these soft cells, on account of the fact that in the petiolar bundle the tracheids form a compact mass and are not separated from each other by any soft cells. Thus if the tyloses, generally so-called, are really formed by the ingrowth of the xylem-sheath cells, these cells must have been in a remarkably active condition to grow to such an extent as to fill all these wide tracheids. It is quite possible that such was actually the case, though one hesitates to ascribe to fossil Ferns an activity not present in recent Ferns, for even in the Tree Ferns, where cavity parenchyma attains its greatest development, and in Nephrolepis, where a single cell can be seen growing through two or three vessels, the activity of the sheath cells occurs only opposite the weak protoxylem vessels : the cells never enter the wide tracheids of the metaxylem. The formation of cavity parenchyma is, of course, of the same nature ; but when one considers the usual extent of the tissue as compared with the extent of the whole bundle, it will at once be seen that there is a great difference between the activity necessary to form cavity parenchyma and that which would be required to form a pseudo-parenchyma throughout the tracheids of the bundle. Gwynne-Vaughan, in a paper read at the British Association at Leicester, 1907, showed that the middle lamella of recent fern tracheids consists of pectose which disappears as the plant becomes older, the lumina of the adjacent xylem elements being thus placed in communication with each other by the disappearance of the pit- 
closing membrane. Such, he also showed, was the case in fossil Ferns, and as there would be no actual resisting membrane over the pits to break through, this renders it somewhat more likely that the cells of the xylem sheath could grow out from one tracheid to another, and so throughout the bundle, just as in the xylem-sheath cells grow out from one spiral vessel to another in the formation of cavity parenchyma. Another argument in favour of the theory that these soft cells in fossil Ferns may be due to the xylem-sheath cells is that a petiole of Rachiopteris (Zygopteris) corrugata was recorded by Weiss ('06) as showing two small lignified tyloses in one of the tracheids, the others being filled by cells having the usual unthickened walls. This, of course, indicates that the tyloses were formed by the ingrowth of a soft wood cell and not by a fungoid organism, for the latter would not be capable of such lignification. Such an example is a strong argument in favour of the view that the soft cells in the tracheids are all due to the ingrowth of soft wood cells. I cannot explain the presence of these lignified tyloses except as being due to an isolated soft cell enclosed within the xylem, such as one occasionally sees in ferns which have a compact mass of xylem. So far as I know, no reference has been made to specimens of Rachiopteris in which tyloses occur only in the tracheids at the periphery of the bundle, as one might reasonably expect if the soft tissue were formed from the xylem-sheath cells, for the tyloses in this case should be formed first in the tracheids immediately adjoining the sheath cells. I have seen slides of Rachiopteris in which some cells, especially the smaller cells, to the outside are empty and others are filled with 'tyloses': some of the tracheids in the interior of the bundle had the soft tissue, others had not: the arrangement was quite irregular. I incline to the opinion that the occurrence in some fossil Ferns of soft pseudo-parenchyma sometimes stopping up the entire mass of tracheids, sometimes stopping up only a proportion, is due to the presence of fungi which had entered the plant. The phenomenon of the expansion of the mycelium of a fungus in the cavities of wood vessels is well known. Referring to the mycelium of the Agaricineae ramifying in the wood of a host plant, Tubeuf and Smith ('97) write: 'The mycelium gradually spreads . . . into the vascular elements of the wood. . . . While previously it was simply filiform and furnished with numerous lateral hyphae, it now develops large bladder-like swellings, and at the same time the hyphae change into a kind of large-meshed parenchyma, which like the tyloses of many dicotyledonous trees completely fills up the lumina of the tracheids.' If the pseudo-parenchyma in fossil wood is due to the xylem sheath, one would expect to see in longitudinal sections evidences of the horizontal extension of these cells from one tracheid to another, such as one sees in modern Ferns, whilst if the tissue is due to fungi there.would be less likelihood of noticing the passage horizontally of a fungal filament; the direction of extension of a fungal filament would be generally 
vertical. In one longitudinal section of Rachiopteris insignis I noticed that in two wide scalariform tracheids adjoining each other, one was filled with pseudo-parenchyma, whilst the adjoining one contained none: there was not even a beginning of growth of the pseudo-parenchyma, as one might have expected, by analogy with cavity-parenchyma formation; in the latter case one vessel does not become entirely filled up with a tissue before sending out processes into the adjoining vessels. A long fungal filament ran vertically in the otherwise empty tracheid. On the whole, it seems to me that there is at least as strong evidence in support of the view that the pseudo-parenchyma in the tracheids of fossil Ferns is due to the presence of fungi as for the view that it is due to the xylem-sheath cells which fill up the lumina of the tracheids by a true process of tylosis.

To Professor Weiss, although I differ from him in my view as to the formation of soft cells in the tracheids of fossil Ferns, I wish to express my indebtedness for help in this piece of work and for the useful suggestions he has made to me from time to time.

UNIVERSITY OF MANCHESTER.

Jansary, 1908.

\section{LiteratuRE.}

Boodle, L. A. ('01): The Comparative Anatomy of the Hymenophyllaceae, Schizeaceae and Gleicheniaceae. Annals of Bot., vol. xv, $190 \mathrm{I}$.

Brebner ('02) : On the Anatomy of Danaea and other Marattiacene, Annals of Bot, vol, xvi.

DipPEL ('04): Mikroskop II and Ueber die Zusammensetzang des Gefässbündels der Kryptogamen. Im amtl. Bericht der 39. Naturforscher-Vers. zn Giessen. Giessen 1864 and 1865.

Gwynne-Vaughan ('08) : Anatomy of the Solenostelic Ferns. Annals of Bot., vol. xvii.

Haberlandt ('96): Planzenanatomie. Leipzig, I 896.

Johnson, J. ('03): Tyloses in the Bracken Fern. Scientific Proceedings of the Royal Dublin Soclety, vol. x, Ig03.

Jordan, Rose ('03) : On some Peculiar Tyloses in Cucumis sativa. New Phytologist, vol.ii, 1903.

Russow (72): Vergleichende Untersuchungen. Mémoires de l'Acad. Imp. des Sci. de SaintPétersbourg, tome xix.

Seward, A. C. ('90): On the Stracture and Affinities of Matonia pectirata. Phil. Trans. Royal Soc. of London, vol. crci, 1899 .

Setward and Ford ('03): The Anatomy of Tadea. Trans. of Linn. Soc. of London, vol. vi, 1903.

Terletzski ('84): Anatomie der Vegetationsorgane von Struthiopteris Germanica nnd Pteris aquilina. Jahrb. für wiss. Bot, , vol. xv, 1884.

Weiss, F. E. ('06): On the Tyloses of Rachiopteris corrugata. New Phytologist, rol, v, Igo6.

Williamson, W. C. ('88) : On some Anomalous Cells developed within the interior of the Vascular and Cellalar Tissues of the Fossil Plants of the Coal Measares. Annals of Bot., vol. 1i, 1888. 


\section{EXPLANATION OF PLATE XXV.}

Illastrating Miss McNicol's Paper on Cavity Parenchyma and Tyloses.

Fig. I. Micralepia platyphylla. Trans. sec. of part of petiolar bundle. en, endodermis $p$, pericycle; $p h$, phloem; $x y$, xylem; $c p$, cavity parenchyma.

Fig. 2. Pteris aquitina. Long. sec. of petiole showing cavity parenchyma.

Fig. 3. The same. Beginning of formation of cavity parenchyma by tylose-like intrusions $t y$ into the spiral vessels $p x$. $m x$, metaxylem; $p x^{1}$, remains of spiral vessels; $n$, nucleas.

Fig. 4. The same. Later stage in the formation of cavity parenchyma.

Fig. 5. The same. Trans. sec. of petiole. con. p., conjunctive parenchyma.

Fig. 6. Alsophila excelsa. Petiole, long. sec. showing cavity parenchyma.

Fig. 7. Dicksonia antartica. Petiole, long. sec. showing cavity parenchyma.

Fig. 8. Cibotium princeps. Trans. sec. of a single 'bay' in the vascular bandle of the petiole. $x s$, xylem sheath; $t$, reticalately lignified tracheid. ressel.

Fig. 9. The same. Enlarged view of strand of $c p . p x^{1}$, the remains of a disintegrated spiral

Fig. ro. The same. Long. sec. of a strand of cavity parenchyma. et, elongated tracheid.

Fig. Ir. Helminthostachys. Semidiagrammatic view of trans. sec. of sterile leaf-stalk.

Fig. I 2. The same. Long. sec. showing $c p$. $b p$, tracheids with bordered plts.

Fig. I 3. A ngiopteris evecta. A single petiolar bundle. sc, secretory cells.

Fig. I4 Marsilia quadrifolia. Bundle of petiole, trans. sec.

Fig. I5. Marsilia quadrifolia. Cavity parenchyma enlarged. e, cavity.

Fig. 16. Marsilia quadrifolia. Long. sec. of cavity parenchyma.

Fig. 17. Loxsoma. Cells of cavity parenchyma-after Gwynne-Vaughan. 
Arnals of Botany

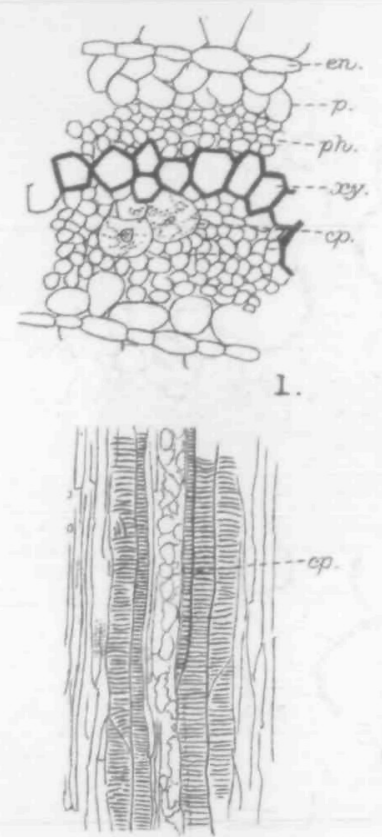

2.
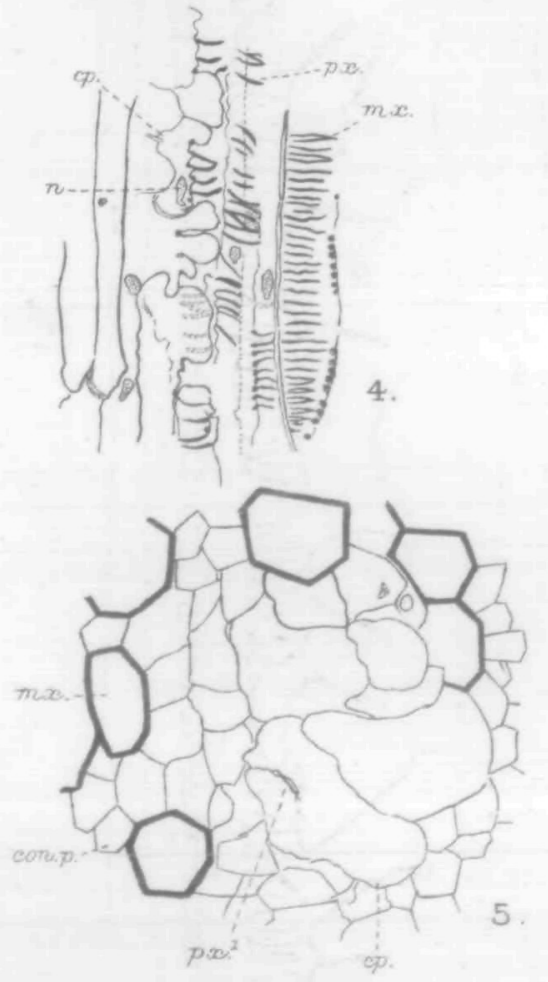

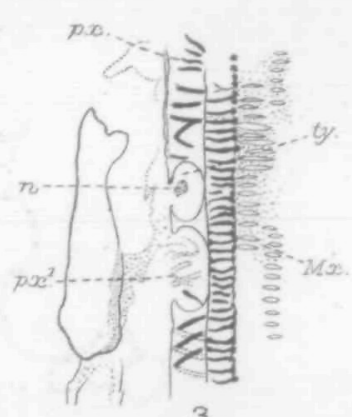

3.

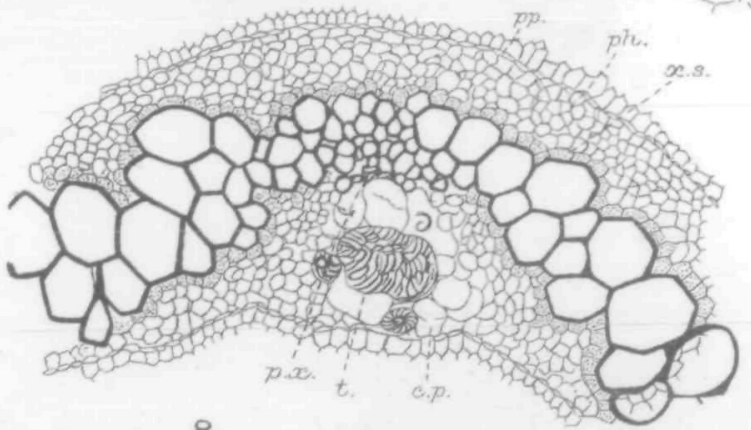

8

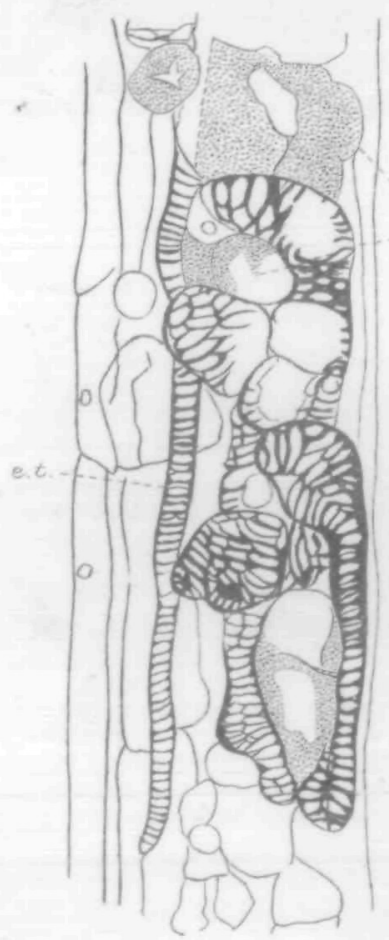

10

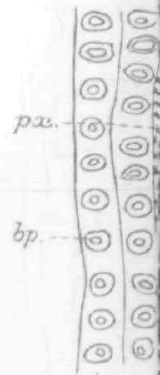

$p 20$

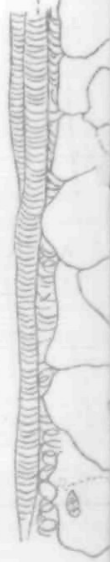




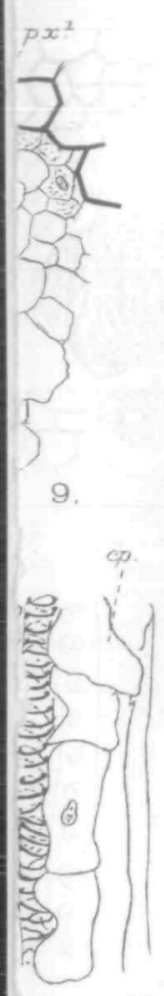

12.

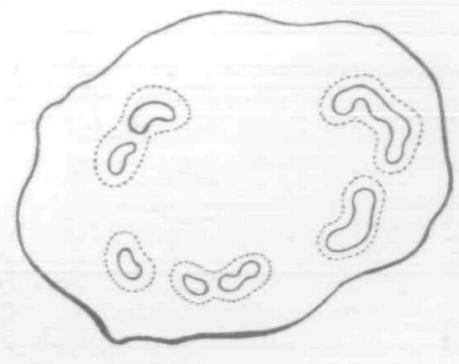

II.

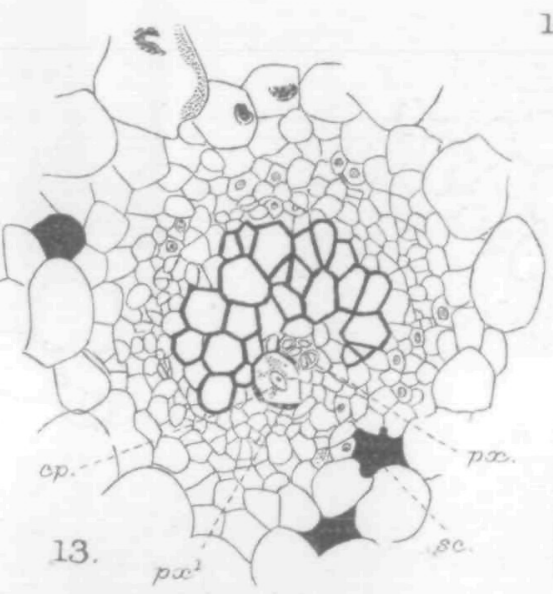

8

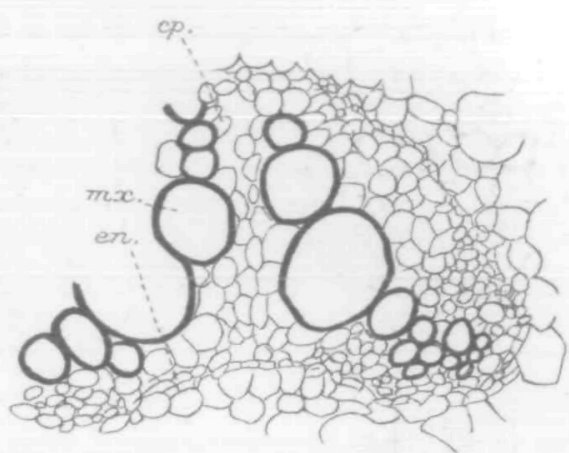

14.
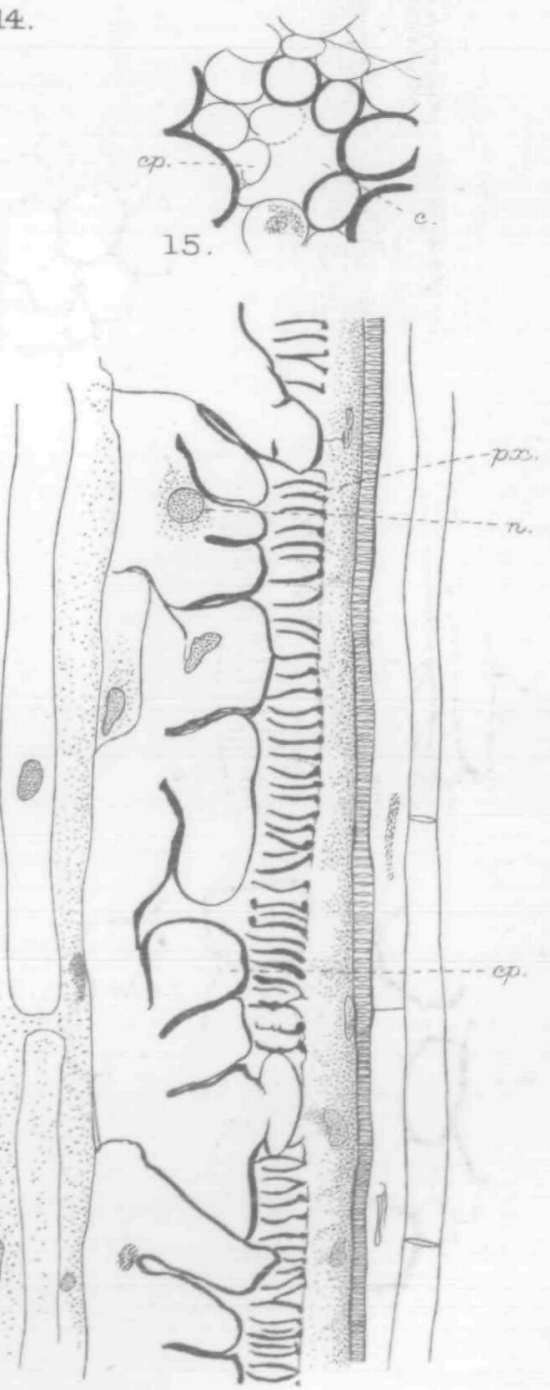
